\title{
Psychosis, central hyperventilation and inappropriate secretion of antidiuretic hormone in systemic lupus erythematosus
}

\author{
G. DeCAUX* \\ M.D.
}

J. UNGER*
M.D.

\author{
C. MARnefFe $\dagger$ \\ M.D. \\ Departments of ${ }^{*}$ Internal Medicine and $\dagger$ Psychiatry, Hôpital Universitaire Saint-Pierre, \\ Rue Haute, 322, Brussels B-1000
}

\begin{abstract}
Summary
A case of systemic lupus erythematosus with reversible psychosis and hyperventilation related to hyponatraemia secondary to a syndrome of inappropriate secretion of antidiuretic hormone (SIADH) is presented. The SIADH was treated successfully by oral urea for more than 8 months.
\end{abstract}

\section{Introduction}

Psychiatric manifestations are frequent in systemic lupus erythematosus (SLE) (Dubois, 1974). A case is reported in which acute psychosis and central hyperventilation were related to low serum sodium secondary to a syndrome of inappropriate secretion of antidiuretic hormone (SIADH). This is believed to be the first report of SIADH as the only clinical manifestation of brain lupus.

\section{Case report}

A 16-year-old boy was admitted with psychosis. When he was 12 years old, a nephrotic syndrome secondary to diffuse membranoproliferative glomerulonephritis associated with SLE had been diagnosed. For 4 years the disease was well controlled by variable doses of steroids and azathioprine. Before admission, he was on $20 \mathrm{mg}$ prednisone every other day, a salt-free diet and $100 \mathrm{mg}$ azathioprine daily. One month before admission, he became logorrheic, hyperactive, and he suffered from insomnia and megalomania. Physical examination was normal except for mania and high blood pressure $(160 / 100 \mathrm{mmHg})$. There was no oedema. Blood urea was $5.5 \mathrm{mmol} / \mathrm{l}$, creatinine $61 \mu \mathrm{mol} / \mathrm{l}$, creatinine clearance $1.07 \mathrm{ml} / \mathrm{s}$, uric acid $0.12 \mathrm{mmol} / \mathrm{l}$, blood glucose $5.3 \mathrm{mmol} / 1$, cholesterol $6.97 \mathrm{mmol} / 1$, serum sodium $113 \mathrm{mmol} / \mathrm{l}$, potassium $3.5 \mathrm{mmol} / 1$, chloride $86 \mathrm{mmol} / 1$, carbon dioxide $18 \mathrm{mmol} / \mathrm{l}$. The arterial $\mathrm{pH}$ was $7 \cdot 51$. Arterial blood gases were $\mathrm{PCO}_{2} 3.33 \mathrm{kPa}$ and $\mathrm{PO}_{2} 17.02 \mathrm{kPa}$ when breathing room air. Urine $\mathrm{pH}$ was 7 . Total protein was $47 \mathrm{~g} / \mathrm{l}$ with $63 \%$ albumin. Blood osmolality was 240 $\mathrm{mmol} / \mathrm{kg} \mathrm{H}_{2} \mathrm{O}$ with a concomitant urine osmolality of $460 \mathrm{mmol} / \mathrm{kg} \mathrm{H}_{2} \mathrm{O}$ and a urine sodium of $105 \mathrm{mmol} / \mathrm{l}$. A 24-hr urine collection contained $2.5 \mathrm{~g}$ protein. Urinalysis was normal. Thyroid function was normal. Plasma renin activity and serum/urinary aldosterone while the patient was on a normal salt diet were normal. Electroencephalogram showed diffuse slow theta waves. Chest X-ray, CT scans of the head and lumbar puncture were normal. Antinuclear factor titre was $1 / 128$; total haemolytic complement, $\mathrm{C}_{3}$ and $\mathrm{C}_{4}$ were normal.

The patient received atenolol $100 \mathrm{mg}$ and urea $30 \mathrm{~g}$ daily (Fig. 1). Urea therapy (Decaux et al., 1980) induced a normalization of serum sodium and simultaneously his behaviour improved. The hyperventilation disappeared and after 12 days' treatment arterial blood gases were $\mathrm{PO}_{2} 13.03 \mathrm{kPa}, \mathrm{PCO}_{2}$ $4.66 \mathrm{kPa}, \mathrm{pH} 7.45$, and carbon dioxide $24 \mathrm{mmol} / \mathrm{l}$. Electroencephalogram was normalized. The next day urea was discontinued and severe water restriction was ordered but not applied by the patient. Two days later, he was acutely psychotic and responded poorly to neuroleptics. Serum sodium was then $118 \mathrm{mmol} / \mathrm{l}$, and respiratory alkalosis was present again. Urea was reinstituted and the mental state rapidly improved, together with normalization of serum sodium and carbon dioxide. A standard urine acidification test (oral ammonium chloride $0.1 \mathrm{~g} / \mathrm{kg}$ body weight) was then performed and was normal. The patient was discharged with $30 \mathrm{~g}$ urea daily and he was allowed to drink 1.5 litre water/day. After 8 months of this regimen, the patient is doing well and the electrolytes remain normal despite the persistence of SIADH. 


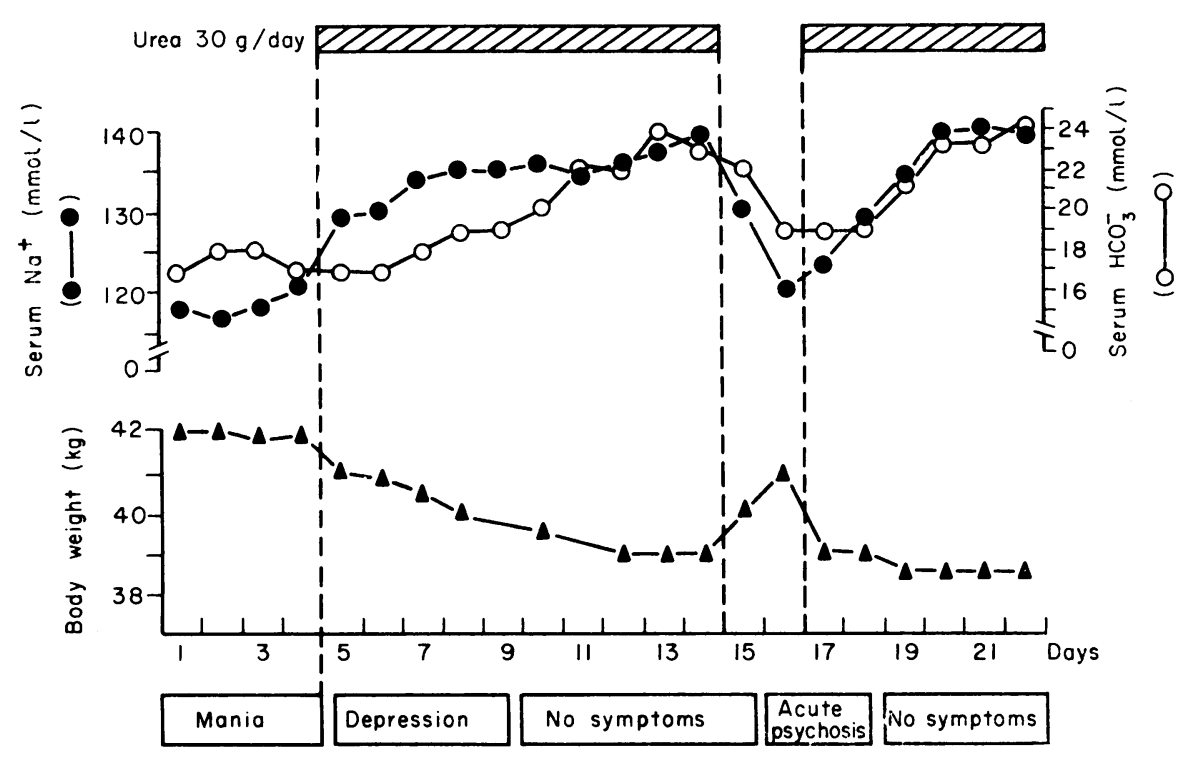

FIG. 1. Evolution of blood and weight parameters during urea therapy.

\section{Discussion}

The main features of this case were that the SIADH was the only evidence for brain lupus, and that psychosis and central hyperventilation were related to hyponatraemia. The hyponatraemia was due to SIADH since urine sodium was low $(10 \mathrm{mmol} / \mathrm{l})$ when the patient was on a salt-free diet and high during normal salt intake $(105 \mathrm{mmol} / \mathrm{l})$, while serum sodium was low. These data excluded a salt-losing nephritis. Drugs, tumour and endocrine failure were not present as causes of SIADH, which was therefore attributed to brain lupus. Such an association has been described in one previous case (Kaplan, Curl and Decker, 1970) but it had more extensive brain lesions. Psychosis in the present patient was clearly related to low serum sodium concentrations. Psychiatric symptoms in SLE are frequent but the possible role of the serum sodium concentration has not yet been mentioned. Central hyperventilation in SLE has been reported (Kaplan et al., 1970; Elkington, 1966) and was related to lesions of the hypothalamus and in the pons (Kaplan et al., 1970); in the present case $\stackrel{\mathbb{\Phi}}{\rightarrow}$ however, hyperventilation disappeared when hypo natraemia and psychosis were cured.

\section{Acknowledgment}

We thank Dr G. Delespesse for allowing us to present hiรू patient.

\section{References}

BARTTER, F.C. \& Schwartz, W.B. (1967) The syndrome of inappropriate secretion of antidiuretic hormone. American Journal of Medicine, 42, 790.

Decaux, G., Brimioulle, S., Genette, F. \& Mockel, J: (1980) Treatment of the syndrome of inappropriate secretion of antidiuretic hormone by urea. Americar. Journal of Medicine, 69, 99.

Dubors, El. (Ed) (1974) Lupus Erythematosus, 2nd edn University of Southern California Press, Los Angeles.

Elkington, J.R. (1966) Clinical disorders of acid-base regulation. Medical Clinics of North America, 50, 1325.

KaPlan, A.P., Curl, F.D. \& Decker, J.L. (1970) Centraf hyperventilation and inappropriate antidiuretic hormone secretion in systemic lupus erythematosus. Americano Journal of Medicine, 48, 661. 